\title{
Optimisation of xylanases production by two Cellulomonas strains and their use for biomass deconstruction
}

\author{
Ornella M Ontañon ${ }^{1} \cdot$ Soma Bedö ${ }^{2} \cdot$ Silvina Ghio $^{1} \cdot$ Mercedes M Garrido $^{1} \cdot$ Juliana Topalian $^{1} \cdot$ Dóra Jahola $^{2}$. \\ Anikó Fehér ${ }^{2}$ - Maria Pia Valacco ${ }^{3} \cdot$ Eleonora Campos $^{1} \cdot$ Csaba Fehér $^{2}$ (D)
}

Received: 8 December 2020 / Revised: 19 March 2021 / Accepted: 18 April 2021 / Published online: 21 May 2021

(C) The Author(s) 2021

\begin{abstract}
One of the main distinguishing features of bacteria belonging to the Cellulomonas genus is their ability to secrete multiple polysaccharide degrading enzymes. However, their application in biomass deconstruction still constitutes a challenge. We addressed the optimisation of the xylanolytic activities in extracellular enzymatic extracts of Cellulomonas sp. B6 and Cellulomonas fimi B-402 for their subsequent application in lignocellulosic biomass hydrolysis by culture in several substrates. As demonstrated by secretomic profiling, wheat bran and waste paper resulted to be suitable inducers for the secretion of xylanases of Cellulomonas sp. B6 and C. fimi B-402, respectively. Both strains showed high xylanolytic activity in culture supernatant although Cellulomonas sp. B6 was the most efficient xylanolytic strain. Upscaling from flasks to fermentation in a bench scale bioreactor resulted in equivalent production of extracellular xylanolytic enzymatic extracts and freeze drying was a successful method for concentration and conservation of the extracellular enzymes, retaining $80 \%$ activity. Moreover, enzymatic cocktails composed of combined extra and intracellular extracts effectively hydrolysed the hemicellulose fraction of extruded barley straw into xylose and xylooligosaccharides.
\end{abstract}

\section{Key points}

- Secreted xylanase activity of Cellulomonas sp. B6 and C. fimi was maximised.

- Biomass-induced extracellular enzymes were identified by proteomic profiling.

- Combinations of extra and intracellular extracts were used for barley straw hydrolysis.

Keywords Cellulomonas $\cdot$ Lignocellulose $\cdot$ Waste valorisation $\cdot$ Lyophilisation $\cdot$ Enzymatic hydrolysis $\cdot$ Secretome analysis

Eleonora Campos

campos.eleonora@inta.gob.ar

Csaba Fehér

feher.csaba@vbk.bme.hu

1 Instituto de Agrobiotecnología y Biología Molecular (IABIMO), Instituto Nacional de Tecnología Agropecuaria (INTA), Consejo Nacional de Investigaciones Científicas y Técnicas (CONICET), De los Reseros y N. Repetto s/n, Hurlingham, B1686IGC Buenos Aires, Argentina

2 Biorefinery Research Group, Department of Applied Biotechnology and Food Science, Budapest University of Technology and Economics (BUTE), Szent Gellért tér 4, Budapest H-1111, Hungary

3 Centro de Estudios Químicos y Biológicos por Espectrometría de Masa (CEQUIBIEM-FCEN), Departamento de Química Biológica Facultad de Ciencias Exactas y Naturales Universidad de Buenos Aires (UBA-IQUIBICEN), Consejo Nacional de Investigaciones Científicas y Técnicas (CONICET), Buenos Aires, Argentina

\section{Introduction}

Lignocellulosic residues can serve as abundant, cheap, and renewable resources for the production of chemicals, platform molecules, fuels and energy to enhance the development of a sustainable bio-economy (De Bhowmick et al. 2018). Deconstruction of lignocellulosic resources into easily fermentable sugars is very important for the efficient valorisation of biomass. Microbial enzymes with cellulolytic and hemicellulolytic activities have a huge potential to be applied in bioprocesses that use lignocellulosic raw materials (Ballesteros 2010; Maitan-Alfenas et al. 2015).

Decomposition of cellulose requires the concerted action of endo- $\beta$-1,4-glucanases (E.C. 3.2.1.4), reducing end-acting cellobiohydrolases (EC 3.2.1.176), exo- $\beta$-1,4-glucanases (E.C. 3.2.1.74), cellulose 1,4- $\beta$-cellobiosidases (non-reducing end) (E.C. 3.2.1.91) and $\beta$-glucosidases (E.C. 3.2.1.21) 
(Juturu and Wu 2014). However, the hydrolytic deconstruction of hemicellulose requires a higher number of different enzymatic activities due to the variability of its composition and structure (Kane and French 2018). Arabinoxylans are complex hemicelluloses which require a well-balanced action of several enzymes for complete hydrolysis: endo-1,4- $\beta$ xylanases (E.C.3.2.1.8), xylan-1,4- $\beta$-xylosidases (E.C.3.2.1.37), $\alpha$-L-arabinofuranosidases (E.C.3.2.1.55), acetylxylan esterases (E.C.3.1.1.72), ferulic/coumaric acid esterases (EC 3.1.1.73) and other specific activities (e.g. $\alpha$-glucuronidases) depending on the exact chemical composition (Fehér 2018; Bhardwaj et al. 2019).

Efficient enzymatic depolymerisation of the carbohydrate content of lignocellulosic raw material is usually a bottle neck in a biorefinery process. This is why prospection of novel enzymes with higher activity on the raw material used under certain process conditions is required. Moreover, in-site enzyme production is highly recommended for an economically viable operating lignocellulosic biorefinery (Siqueira et al. 2020). Lignocellulosic residues can be used as carbon source for the production of efficient enzyme cocktails within a biorefinery (on-site enzyme production), in order to fulfil or supplement the enzymatic requirements of the process (Astolfi et al. 2019). Cheap and abundant lignocellulose resources, such as wheat bran (Apprich et al. 2014), corn cob (Arumugam and Anandakumar 2016) and paper residues (Wang et al. 2012), have a great potential to be used as the carbon source for biomass degrading enzymes production. The utilisation of lignocellulosic biomass for on-site enzyme production not only can contribute to an efficient waste management, but also offers a sustainable utilisation of these materials adding value to by-products (Das et al. 2013).

In the last decades major research efforts have been made to investigate the production and use of fungal enzymes in biomass conversion. However, there is also a growing interest in the production and application of bacterial enzymes due to their high diversity for several $\mathrm{pH}$ and temperature conditions. The fermentation for bacterial enzyme production offers several advantages including high cell growth rate, robustness and low nutritional requirements, resulting in efficient and cheap processes for enzyme production (Maki et al. 2009; Akhtar et al. 2016). Bacteria belonging to the genera Clostridium, Cellulomonas, Bacillus, Ruminococcus, Bacteroides, Acetovibrio, Streptomyces, and Paenibacillus have been identified as cellulolytic enzyme producers under aerobic or anaerobic culture conditions, depending on the species (Islam 2019). The (hemi)cellulolytic potential of strains belonging to the Cellulomonas genus, such as Cellulomonas fimi ATCC 484 (Wakarchuk et al. 2016) and Cellulomonas sp. B6 (Piccinni et al. 2019) has been demonstrated.

In the present work, we studied the use of different lignocellulosic by-products (wheat bran, corn cob, and waste paper) as carbon sources for C. fimi and Cellulomonas sp. B6 growth, and also evaluated these feedstocks as inducers of xylanases production and secretion. Additionally, we analysed enzyme production in lab scale bioreactors, studied their potential to deconstruct agro-industrial wastes and evaluated lyophilisation as a method for concentration and conservation of the enzymatic extract.

\section{Materials and methods}

\section{Microorganisms}

C. fimi B-402 was obtained from NRRL Agricultural Research Service Culture Collection (IL, USA). Cellulomonas sp. B6 was isolated from a bacterial consortium obtained from a preserved native subtropical forest soil sample (Piccinni et al. 2016). Strain Cellulomonas sp. B6 has been deposited in public collections DSMZ and NCIMB, as DSM 107934 and NCIMB 15124, respectively. The strains were maintained for long term in Luria-Bertani (LB) medium (10 $\mathrm{g} / \mathrm{L}$ tryptone, $5 \mathrm{~g} / \mathrm{L}$ yeast extract, $10 \mathrm{~g} / \mathrm{L} \mathrm{NaCl}$ ) (Bertani 1951) with $20 \% \mathrm{w} / \mathrm{w}$ glycerol at $-80^{\circ} \mathrm{C}$. Before use, a loopfull was spread in LB agar plates (LB supplemented by $15 \mathrm{~g} / \mathrm{L}$ agar) for single colonies isolation.

\section{Model substrates and biomass feedstocks}

Different carbon sources were tested for cell growth and enzyme secretion. Solka-floc (SF, kindly donated by Lund University, Lund, Sweden) and carboxymethyl cellulose of low viscosity (CMC, Sigma-Aldrich, STL, USA) were used as model substrates. The selection of CMC was due to its high purity and solubility in aqueous solutions. SF is a model substrate obtained from milled pinewood through several extraction steps and it has around $76 \% \mathrm{w} / \mathrm{w}$ cellulose and $12 \% \mathrm{w} / \mathrm{w}$ hemicellulose, in terms of dry matter content, and which is insoluble in water (Sipos et al. 2010). Wheat bran (WB), pretreated sweet corn cob (PSCC) and pre-treated waste paper (PWP) were used as lignocellulosic carbon sources. Sweet corn cob pre-treated by alkali extrusion was provided by INRA (Toulouse, France). Waste paper consisted of corrugated cardboard pieces, which were cut into small pieces (smaller than $0.5 \mathrm{~cm}$ ), mixed with distilled water to set $10 \% \mathrm{w} / \mathrm{w}$ dry matter content, homogenised with a hand blender for $10 \mathrm{~min}$ and autoclaved $\left(121{ }^{\circ} \mathrm{C}\right.$ for $\left.30 \mathrm{~min}\right)$. Wheat bran was purchased at a dietary shop.

For enzymatic hydrolysis experiments, extruded barley straw (EBS) was used. EBS was obtained from the Babetreal5 project (https://www.babet-real5.eu/) and provided by CIEMAT (Madrid, Spain). The extrusion conditions were $100{ }^{\circ} \mathrm{C}, 4.5 \% \mathrm{NaOH} /$ dry barley straw and neutralisation with $\mathrm{H}_{3} \mathrm{PO}_{4}$ (Duque et al. 2017). 
Structural carbohydrates (glucan, xylan and arabinan) and the acid insoluble solids of WB and PWP were determined as described by the National Renewable Energy Laboratory (DEN, USA) (Sluiter et al. 2012). Relative composition of PSCC was provided by INRA. The structural carbohydrate analyses of WB and PWP were carried out in triplicates. Starch content of WB was also determined by using enzymatic treatment with $\alpha$-amylase as detailed by Bedö et al. (2019). Composition of PSCC, WB and PWP is detailed in Table 1.

\section{Enzyme production in shake flask}

Bacteria (C. fimi and Cellulomonas sp. B6) were grown on minimal medium $(\mathrm{MM})(1.67 \mathrm{~g} / \mathrm{L}$ dipotassium hydrogen phosphate $\left(\mathrm{K}_{2} \mathrm{HPO}_{4}\right), 0.87 \mathrm{~g} / \mathrm{L}$ potassium dihydrogen phosphate $\left(\mathrm{KH}_{2} \mathrm{PO}_{4}\right), 0.05 \mathrm{~g} / \mathrm{L}$ sodium chloride $(\mathrm{NaCl}), 0.1 \mathrm{~g} / \mathrm{L}$ magnesium sulphate $\left(\mathrm{MgSO}_{4} \times 7 \mathrm{H}_{2} \mathrm{O}\right), 0.04 \mathrm{~g} / \mathrm{L}$ calcium chloride $\left(\mathrm{CaCl}_{2}\right), 0.004 \mathrm{~g} / \mathrm{L}$ iron(III) chloride $\left(\mathrm{FeCl}_{3}\right), 0.005 \mathrm{~g} / \mathrm{L}$ sodium molybdate $\left(\mathrm{NaMoO}_{4} \times 2 \mathrm{H}_{2} \mathrm{O}\right), 0.01 \mathrm{~g} / \mathrm{L}$ biotin, $0.02 \mathrm{~g} /$ $\mathrm{L}$ nicotinic acid, $0.01 \mathrm{~g} / \mathrm{L}$ pantothenic acid, $1 \mathrm{~g} / \mathrm{L}$ ammonium chloride $\left(\mathrm{NH}_{4} \mathrm{Cl}\right)$ ) supplemented with $1 \mathrm{~g} / \mathrm{L}$ yeast extract and $1 \% \mathrm{w} / \mathrm{w}$ of different model substrates (SF, CMC) or $1 \% \mathrm{w} / \mathrm{w}$ of different types of biomass as carbon source (WB, PWP or PSCC as indicated). The MM culture media (without microelements) with the substrates was sterilised in autoclave at 121 ${ }^{\circ} \mathrm{C}$ for $20 \mathrm{~min}$, after which microelements $\left(\mathrm{FeCl}_{3}\right.$, $\mathrm{NaMoO}_{4} \times 2 \mathrm{H}_{2} \mathrm{O}$, biotin, nicotinic acid and pantothenic acid) were added to the indicated concentration. Starter cultures were obtained by inoculating single colonies (from fresh agar plates) in $10 \mathrm{~mL} \mathrm{LB}$ medium and incubating at $30{ }^{\circ} \mathrm{C}$ and $220 \mathrm{rpm}$ for $24 \mathrm{~h}$, in the case of Cellulomonas sp. B6, and for $72 \mathrm{~h}$, in the case of $C$. fimi. Cultures were inoculated from the starter cultures to obtain an initial cell concentration that corresponds to an optical density (OD) of 0.05 . Cultures were carried out in $20 \mathrm{~mL}$ culture media filled in $100-\mathrm{mL}$ shake

Table 1 Relative structural carbohydrate content of the lignocellulosic substrates

\begin{tabular}{llll}
\hline & \multicolumn{2}{l}{ Percentage of dry matter } \\
\cline { 2 - 4 } & PSCC $^{*}$ & WB $^{* *}$ & PWP $^{* *}$ \\
\hline Glucan & 34.0 & $34.1(0.1)$ & $55.8(0.2)$ \\
Xylan & 22.6 & $18.0(0.2)$ & $13.2(0.3)$ \\
Arabinan & 9.3 & $9.5(0.4)$ & $1.2(0.3)$ \\
Acid insoluble solid (Klason-lignin) & 13.2 & $7.5(0.5)$ & $11.5(0.1)$ \\
\hline
\end{tabular}

$P S C C$ pre-treated sweet corn cob, $W B$ wheat bran, $P W P$ pre-treated waste paper

* Data provided by INRA

** Data determined in this study. Average values and standard deviations (indicated in parentheses) are calculated from triplicates flasks, at $30^{\circ} \mathrm{C}$ and $220 \mathrm{rpm}$ for $72 \mathrm{~h}$. Cultures were performed in triplicates.

\section{Enzyme production in bench-top bioreactor}

Enzyme production of C. fimi and Cellulomonas sp. B6 was performed in 500-mL bench-top bioreactors (JFermi Ltd., Jenö, Hungary) filled with $300 \mathrm{~mL}$ of MM medium supplemented with $1 \% \mathrm{w} / \mathrm{w}$ PWP and WB, respectively. Bacteria were first grown as starter cultures in LB medium and then inoculated into the MM supplemented with biomass to get an initial cell concentration that corresponds to an OD of 0.05 . Enzyme productions, in duplicates, were accomplished at 30 ${ }^{\circ} \mathrm{C}$ for $72 \mathrm{~h}$ with daily sampling. The bioreactors were equipped to be able to control dissolved oxygen (DO) level by adjusting the agitation and air flow rate, and to monitor the $\mathrm{pH}$ in the culture medium. DO level was kept at $20 \%$ of saturation in order to ensure that the culture was maintained in aerobic conditions.

\section{Production of extracellular enzyme fraction and intracellular enzyme fraction}

When the culture of enzyme production reached late exponential phase $(72 \mathrm{~h})$, the remaining solid biomass and the obtained cell mass were separated from the supernatant by centrifugation $(6000 \times g, 10 \mathrm{~min})$. The supernatants are referred to as extracellular enzyme (EE) fractions. EE fractions were supplemented with $0.04 \% \mathrm{w} / \mathrm{w}$ sodium azide and kept at $4{ }^{\circ} \mathrm{C}$ until use. The cells and remaining biomass (centrifugation pellet) were resuspended in citrate buffer $(100 \mathrm{mM}, \mathrm{pH} 6)$ in a ratio of 1:10 regarding the initial culture volume, ultrasonicated on ice (six pulses of $10 \mathrm{~s}, 28 \%$ amplitude) and centrifuged $(10000 \times g, 30 \mathrm{~min})$. After centrifugation, filtered supernatants were used as intracellular enzyme (IE) fractions.

\section{Lyophilisation of EE and IE fractions}

$\mathrm{EE}$ and IE fractions were frozen at $-80^{\circ} \mathrm{C}$. Then, they were taken into the freeze-dryer (EDWARDS Super Modulyo Freeze Dryer, Thermo Electron Corp., Waltham, MA, USA), treated at $-30^{\circ} \mathrm{C}$ under $1 \times 10^{-1}$ mbar vacuum for $48 \mathrm{~h}$ and stored at $4{ }^{\circ} \mathrm{C}$. The lyophilised enzyme fractions were referred to as LEE and LIE in the cases of extracellular and intracellular enzyme fractions, respectively. For enzymatic assays, both fractions were resuspended with sterile water to the original volume. Ten times concentrated enzyme fraction of LEE (LEE $(10 \times)$ ) was also produced by dissolving LEE in appropriate amount of sterile water. Recovery of the xylanase activity was calculated as the ratio between xylanase activity after and before lyophilisation and expressed as a percentage. Lyophilisation experiments were performed in triplicates. 


\section{Enzymatic activity measurements}

Xylanase and CMCase activities were assayed in microtubes using beechwood xylan $(1 \% \mathrm{w} / \mathrm{w})$ or CMC $(2 \% \mathrm{w} / \mathrm{w})$ as substrates, respectively (Ghio et al. 2012). For these assays, $0.1 \mathrm{~mL}$ of appropriately diluted extracts (EE, IC, LEE, LEE $(10 \times)$ or LIE) were added to $0.1 \mathrm{~mL}$ of each substrate prepared in citrate buffer ( $\mathrm{pH} 6$ ). Hydrolysis reactions were carried out at $40{ }^{\circ} \mathrm{C}$, $400 \mathrm{rpm}$ for $10 \mathrm{~min}$. These conditions were established in a previous work (Piccinni et al. 2019). Reducing sugars released from the reactions were measured by dinitrosalicylic acid (DNS) method (Miller 1959) using glucose or xylose standard curves.

$\beta$-Glucosidase, cellobiohydrolase, $\beta$-xylosidase and $\alpha$-larabinofuranosidase activities were assayed, using $5 \mathrm{mM} p$ nitrophenyl- $\beta$-D-glucopyranoside ( $p$ NPG), $p$-nitrophenyl- $\beta$ D-cellobioside ( $p$ NPC), $p$-nitrophenyl- $\beta$-D-xylopyranoside $(p$ NPX) and $p$-nitrophenyl- $\alpha$-L-arabinofuranoside ( $p$ NPA) (Sigma-Aldrich, STL, USA) as substrates, according to previously established protocols (Ontañon et al. 2018). In brief, reactions were performed by combining $100 \mu \mathrm{L}$ of LEE $(10 \times)$ or LIE fraction with $100 \mu \mathrm{L}$ of $2.5 \mathrm{mM}$ substrate in citrate buffer $(\mathrm{pH} 6,100 \mathrm{mM})$, and incubating at $40{ }^{\circ} \mathrm{C}$ for $20 \mathrm{~min}$. Reactions were stopped with $500 \mu \mathrm{L}$ of $2 \% \mathrm{w} / \mathrm{w}$ sodium carbonate and absorbance was determined at 410 $\mathrm{nm}$. A $p$-nitrophenol ( $p \mathrm{NP})$ curve was used as a standard.

All enzymatic assays were conducted in triplicates and controls of enzyme without substrate and substrate without enzyme were included. In all cases, one international unit (U) was defined as the amount of enzyme required to release $1 \mu \mathrm{mol}$ of product per minute under the assay conditions.

\section{Analysis of secretome}

Secretomic analysis was performed using flasks cultures of Cellulomonas sp. B6 in WB and C. fimi in PWP, in duplicate according to the protocol previously described by Piccinni et al. (2019). Briefly, total proteins contained in cell-free supernatants were quantified by Bradford assay (Promega, Biodynamics, CABA, Argentina), precipitated with $10 \% \mathrm{w} / \mathrm{w}$ trichloroacetic acid and then resuspended in ultrapure water (resistivity of 18.2 $\mathrm{M} \Omega \times \mathrm{cm}$ ) to a final concentration of $1 \mathrm{mg} / \mathrm{mL}$. Protein digestion and mass spectrometry analysis were performed at CEQUIBIEM (http://cequibiem.qb.fcen.uba.ar/). Proteins were reduced with dithiotreitol $10 \mathrm{mmol} / \mathrm{L}$ for $45 \mathrm{~min}$ at $56{ }^{\circ} \mathrm{C}$, alkylated with iodoacetamide $(55 \mathrm{mmol} / \mathrm{L})$ for $45 \mathrm{~min}$ in the dark and digested with trypsin (PromegaV5111; Promega, Fitchburg, WI, USA) overnight at $37{ }^{\circ} \mathrm{C}$. The digests were analysed by nano LC-MS/MS in a Thermo Scientific QExactive Mass Spectrometer coupled with a nano HPLC EASY-nLC 1000 (ThermoFisher Scientific, Waltham, MA, USA). The MS equipment has a high collision dissociation cell (HCD) for fragmentation and an Orbitrap analyser (ThermoFisher Scientific; Q-Exactive, Waltham, MA, USA).
XCALIBUR 3.0.63 (ThermoFisher Scientific, Waltham, MA, USA) software was used for data acquisition and equipment configuration to allow peptides identification at the same time of their chromatographic separation. Full-scan mass spectra were acquired in the Orbitrap analyser. The scanned mass range was $400-2000 \mathrm{~m} / \mathrm{z}$, at a resolution of 70,000 at $400 \mathrm{~m} / \mathrm{z}$, and the 12 most intense ions in each cycle were sequentially isolated, fragmented by HCD and measured in the Orbitrap analyser. Peptides with a charge of +1 or with unassigned charge state were excluded from fragmentation for MS2. QExactive raw data were processed using PROTEOME DISCOVERER software (ver. 2.1.1.21; ThermoFisher Scientific, Waltham, MA, USA) and searched against Cellulomonas sp. B6 or C. fimi ATCC 484 UniProt sequences database (based on genome full sequences GenBank access LNTD00000000.1 and GCA_000212695.1, respectively), with trypsin specificity and a maximum of one missed cleavage per peptide. Proteome Discoverer searches were performed with a precursor mass tolerance of $10 \mathrm{ppm}$ and product ion tolerance to $0.05 \mathrm{Da}$. Static modifications were set to carbamidomethylation of Cys, and dynamic modifications were set to oxidation of Met and N-terminal acetylation. Protein hits were filtered for high confidence peptide matches with a maximum protein and peptide false discovery rate of $1 \%$ calculated by employing a reverse database strategy. A minimum of two unique peptides was considered as confident detection. For the estimation of relative abundance, we used the protein abundance index emPAI calculated by Sequest using protein identification data. The equation emPAI $/ \Sigma(\mathrm{emPAI}) \times$ 100 was used to calculate the protein content in mol.\% (emPAI\%) (Ishihama et al. 2005; Shinoda et al. 2009). The mass spectrometry proteomics data have been deposited to the ProteomeXchange Consortium via the PRIDE partner repository with the dataset identifier PXD022718.

\section{Enzymatic hydrolysis of EBS and analysis of the hydrolysates}

Enzymatic hydrolysis experiments on EBS were performed by using LEE fraction and a combination of LEE and IE fractions with different mixing ratios and dilutions. Enzymatic hydrolysis experiments were carried out in a reaction mixture containing $5 \% \mathrm{w} / \mathrm{v}$ dry EBS in citrate buffer ( $\mathrm{pH} 6,100 \mathrm{mM})$. The hydrolysis reactions were carried out at $45{ }^{\circ} \mathrm{C}, 220 \mathrm{rpm}$ for $72 \mathrm{~h}$ and stopped by boiling for $5 \mathrm{~min}$. The supernatant was clarified by centrifugation $(6000 \times \mathrm{g}, 15 \mathrm{~min})$ and then used to measure the xylose released from the biomass employing D-xylose assay kit (Megazyme, Bray, Ireland). The hydrolysis products were analysed by thin layer chromatography (TLC) in silica gel plates using butanol/acetic acid/water (2:1:1) as solvents and revealed by water/ ethanol/sulfuric acid (20:70:3) with $1 \% \mathrm{v} / \mathrm{v}$ orcinol solution over flame. 


\section{Results}

\section{Xylanase and CMCase activities of EE fractions obtained using different biomass feedstocks as carbon source}

C. fimi and Cellulomonas sp. B6 were cultivated on MM supplemented with different lignocellulosic residues as carbon source in order to study the production and secretion of polysaccharide active enzymes (CAZYmes). The carbon sources evaluated in this study were Solka-floc (SF) and carboxymethyl cellulose (CMC) as model cellulosic substrates, and pre-treated waste paper (PWP), wheat bran (WB) and pre-treated sweet corn cob (PSCC) as lignocellulosic materials. The most suitable substrates for culture were selected based on the enzymatic activities measured in the EE fractions. In the case of Cellulomonas sp. B6, the highest xylanase activity $(3.06 \mathrm{U} / \mathrm{mL})$ was obtained using WB. Xylanase activities produced using PWP and PSCC were $60.6 \%$ and $50.5 \%$, respectively, compared to the maximal activity $(100 \%)$ reached on WB while SF and CMC (model cellulosic substrates) resulted in $21.4 \%$ and $12.1 \%$ relative xylanase activities, respectively (Fig. 1a).

The highest xylanase activity $(1.32 \mathrm{U} / \mathrm{mL})$ of the EE fractions produced by $C$. fimi was achieved by using PWP as the carbon source (Fig. 1b). Surprisingly, the second highest xylanase activity was obtained when SF was used, corresponding to $76.1 \%$ activity of the activity achieved on PWP (100\%) (Fig. 1b). WB and PSCC resulted in relative xylanase activities of $41.5 \%$ and $47.6 \%$, respectively, and the lowest relative xylanase activity $(17.4 \%)$ was observed with CMC (Fig. 1b). These results suggested that the cellulose-rich, chemically not-modified substrates (SF and PWP) were good inducers for the extracellular production of xylanases by C. fimi.

CMCase (glucanase) activities of the EE fractions obtained with the different carbon sources by $C$. fimi and Cellulomonas sp. B6 were below $0.2 \mathrm{U} / \mathrm{mL}$ in all the cases and were therefore not further studied.

\section{Enzyme production in bench-top bioreactor}

Based on the results described in the previous section, WB and PWP were selected as the best carbon sources for extracellular xylanase production by Cellulomonas sp. B6 and C. fimi, respectively. Hence, scale-up experiments from shake flask to a bench-top bioreactor ( $300 \mathrm{~mL}$ culture volume) were performed only with these raw materials. The culture profile of Cellulomonas sp. B6 using 1\% w/w WB is shown in Fig. 2. Apart from small deviations in the first $20 \mathrm{~h}$, the $\mathrm{pH}$ remained nearly constant $(\mathrm{pH}$ 6.8) throughout the experiment; which suggests the absence of $\mathrm{pH}$ active by-products, at least in considerable amounts. After $24 \mathrm{~h}$, the DO level started to
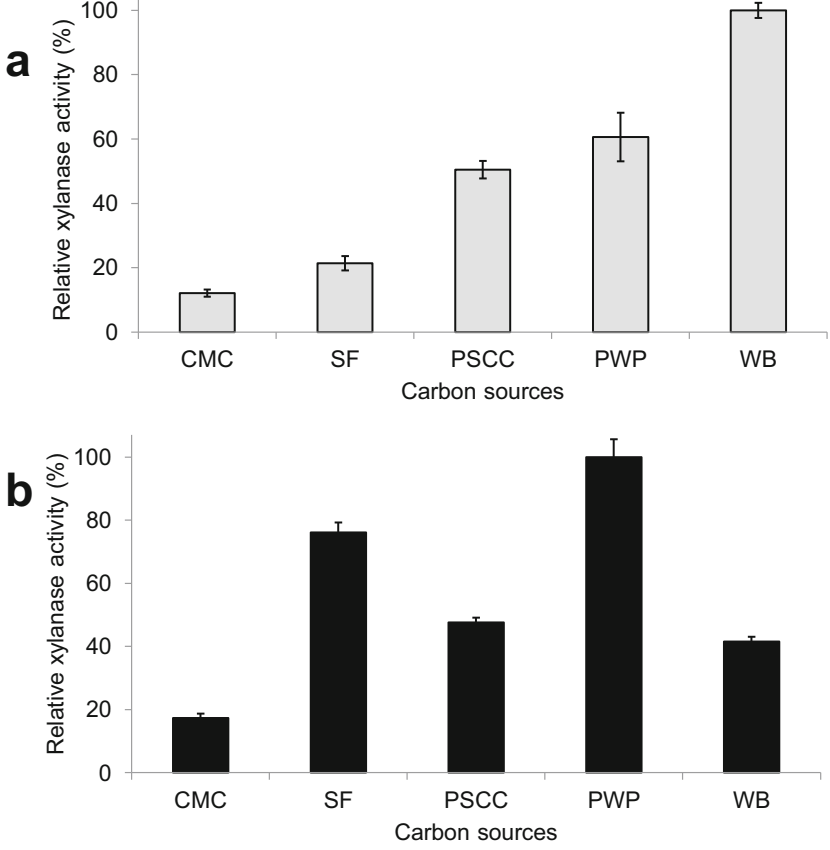

Fig. 1 Relative xylanase activities of extracellular enzyme fractions produced by Cellulomonas sp. B6 (a) and C. fimi (b) on different carbon sources, from $72 \mathrm{~h}$ cultures. CMC: carboxymethyl cellulose, SF: Solka-floc, PSCC: pre-treated sweet corn cob, PWP: pre-treated waste paper, WB: wheat bran. Bars represent average values and standard deviation of triplicate cultures. Relative activities are expressed as the percentage of the maximal activity which was achieved on WB and PWP in the cases of Cellulomonas sp. B6 and C. fimi, respectively

increase, indicating a decrease of cell growth and/or metabolic activity of the cells. After $48 \mathrm{~h}$, the DO level and $\mathrm{CO}_{2}$ concentration in the exhaust gas became nearly constant (Fig. 2).

The xylanase activity displayed a significant increase after $24 \mathrm{~h}$ and reached the highest activity at $48 \mathrm{~h}$ for Cellulomonas sp. B6 and at $72 \mathrm{~h}$ for $C$. fimi (Fig. 3). Under these conditions, the extracellular xylanase activity of $C$. fimi was lower than that of Cellulomonas sp. B6, which is consistent with the results obtained in flasks.

The extracellular xylanase activity for Cellulomonas sp. B6 grown in bench-top bioreactor $(\sim 3 \mathrm{U} / \mathrm{mL})$ was similar to that obtained when grown in flasks $(3.06 \mathrm{U} / \mathrm{mL})$, after $72 \mathrm{~h}$ of fermentation using WB. For $C$. fimi, the outcome was similar: similar xylanase activities either grown in shake flask or bioreactor using PWP $(\sim 1.4 \mathrm{U} / \mathrm{mL})$. These results prove the scalability of the process. After 2 days of fermentation, the xylanase activity in the EE fraction of Cellulomonas sp. B6 was three times higher than that of in the EE fraction of C. fimi.

\section{Secretome analysis}

With the aim to correlate the observed xylanase activity with the specific secreted proteins, extracellular extracts (EE) were analysed by mass spectrometry, in duplicate independent 
Fig. 2 Profile of Cellulomonas sp. B6 cultures on wheat bran (WB) in bench-top bioreactor (3L). Temperature and $\mathrm{pH}$ were maintained at $30^{\circ} \mathrm{C}$ and 7 , respectively

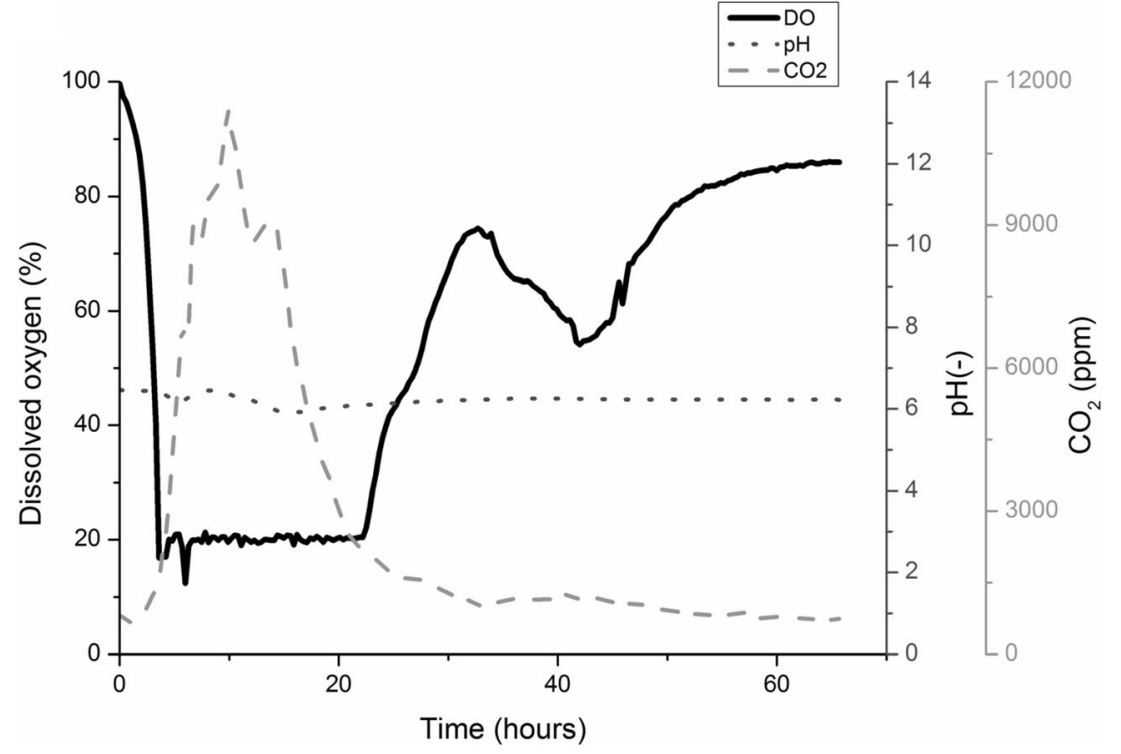

cultures for each strain. In the WB extracellular fraction of Cellulomonas sp. B6, 197 proteins were detected in both samples. In the case of $C$. fimi PWP extracellular fraction, 360 total proteins were identified in both samples. From all of these proteins, 28 and 25 corresponded to glycoside hydrolases (GH) in Cellulomonas sp. B6 and C. fimi, respectively (Table 2). Cellulomonas sp. B6 secreted a repertoire of xylansases (7 GH10 and 1 GH11), which could account for the high xylanase activity in the culture supernatant. In particular, 4 of these xylanases ( 3 GH10 and 1 GH11) were amongst the most abundant proteins in the extract (from 0.77 to $10 \%$ of

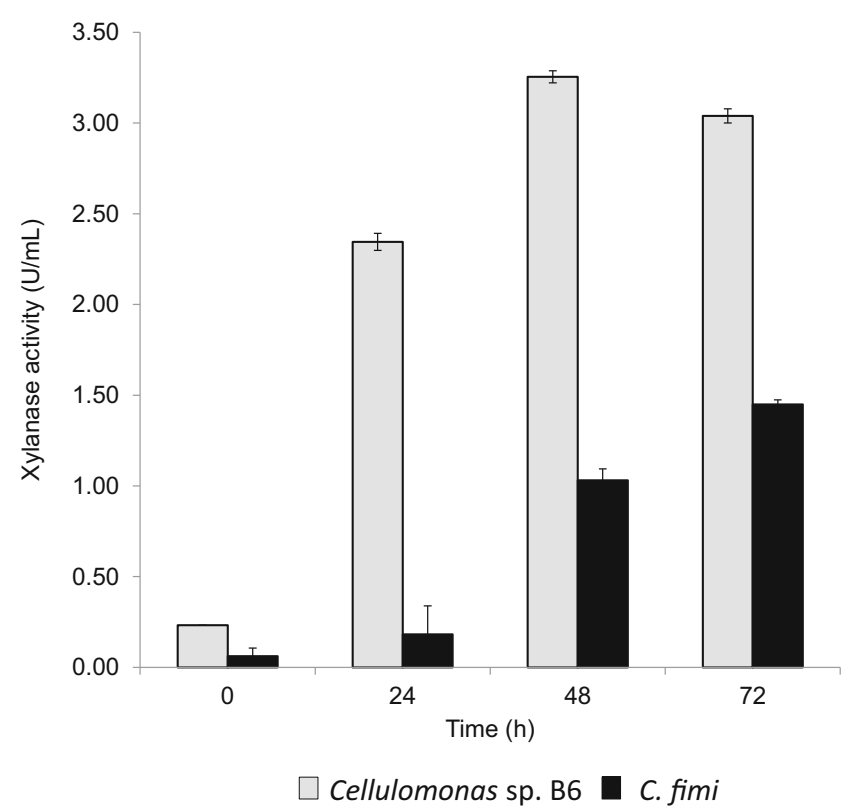

Fig. 3 Extracellular xylanase activities during the aerobic culture of Cellulomonas sp. B6 (grey bars) and C. fimi (black bars) on WB and PWP, respectively, in bench-top bioreactor. WB: wheat bran, PWP: pre-treated waste paper total proteins secreted), based on the index of relative abundance (emPAI\%). The most abundant putative CAZymes in the WB secretome were a GH62 $\alpha$-L-arabinofuranosidase (a debranching enzyme), two GH10 xylanases, a GH6 exoglucanase and a GH9 endoglucanse. As in previous studies, a high abundance of extracellular components of putative ABC transporters were also identified (Piccinni et al. 2019). By culture in PWP, C. fimi secreted 4 GH10 (out of the 5 GH10 encoded in the genome) and 1 GH11 (the only one predicted). The most abundant protein was a xylanase (UNIPROT id F4H4N7) which represented around $15 \%$ of total proteins, followed by a GH9 endoglucanase (about 3\%) and three other xylanases ( 0.5 to $1.5 \%$ of total proteins) (Table 2).

\section{Activities of lyophilised extracts of Cellulomonas sp. B6}

As Cellulomonas sp. B6 presented the highest xylanase activity in the secreted fraction, and this activity correlated with a higher number of xylanases identified in the secretome, this strain was chosen for further studies. Lyophilisation of the enzymatic extracts (EE and IE fractions) produced by Cellulomonas sp. B6 growing on WB was analysed in order to provide an efficient method to preserve enzymatic activities and concentrate the fractions. Lyophilisation of EE fraction (LEE) of Cellulomonas sp. B6 resulted in $80 \%$ recovery of xylanase activity and could be concentrated 10 times (LEE $(10 \times))$. The IE fraction was not further concentrated after lyophilisation (LIE). Beyond the main xylanase activity, $\beta$ xylosidase, $\alpha$-arabinofuranosidase, CMCase, $\beta$-glucosidase and cellobiohydrolase activities of LEE (10×) and LIE fractions were also determined (Table 3 ). While xylanase activity was more than 10 times lower in LIE fraction compared to that 
Table 2 Glycoside hydrolases (GH) identified in the culture supernatants of Cellulomonas sp. B6 and Cellulomonas fimi grown on wheat bran (WB) and pre-treated waste paper (PWP), respectively, (72 h, duplicate cultures). Proteins were identified by mass spectrometry and the relative abundance index (emPAI\%) was calculated in each sample (named as 1 and 2) by Sequest using protein identification data

\begin{tabular}{|c|c|c|c|}
\hline Accession UNIPROT & CAZY domains and protein probable function description & emPAI\% & \\
\hline & & B6 (WB)1 & B6 (WB)2 \\
\hline A0A0V8TB53 & GH10 $\beta$-xylanase & 9.67 & 3.76 \\
\hline A0A0V8TA57 & GH9-CBM4 endo-glucanase & 8.67 & 4.98 \\
\hline A0A0V8S5R6 & GH6 exo-glucanase & 7.47 & 2.00 \\
\hline A0A0V8SBR8 & GH62-CBM13 $\alpha$-L-arabinofuranosidase & 5.58 & 14.13 \\
\hline A0A0V8SJU5 & GH10-CBM2 $\beta$-xylanase & 4.81 & 3.76 \\
\hline A0A0V8SMW4 & GH10-CBM13 $\beta$-xylanase & 2.02 & 0.85 \\
\hline A0A0V8TC27 & GH6-CBM2 endo-glucanase & 1.35 & 0.66 \\
\hline A0A0V8ST89 & GH10-CBM9 $\beta$-xylanase & 1.10 & 1.22 \\
\hline A0A0V8SFL7 & GH11-CBM2 endo-1,4- $\beta$-xylanase & 0.77 & 1.77 \\
\hline A0A0V8S6F9 & GH48-CBM2 exoglucanase & 0.62 & 0.29 \\
\hline A0A0V8T9P9 & GH9 endoglucanase & 0.58 & 0.49 \\
\hline A0A0V8SE95 & GH18-CBM2 chitinase & 0.56 & 0.56 \\
\hline A0A0V8T9W1 & GH10 xylanase & 0.37 & 0.61 \\
\hline A0A0V8T944 & GH9-CBM2 endoglucanase & 0.36 & 0.36 \\
\hline A0A0V8S2E5 & GH5 endoglucanase & 0.32 & 0.70 \\
\hline A0A0V8SBG4 & GH16-CBM13 1,3- $\beta$-glucanase & 0.29 & 0.29 \\
\hline A0A0V8T8K7 & GH5 $\beta$-mannosidase & 0.28 & 0.46 \\
\hline A0A0V8TC25 & GH27-CBM13 $\alpha$-galactosidase & 0.18 & 0.18 \\
\hline A0A0V8SMY7 & GH43-CBM13 $\beta$-xylosidase & 0.14 & 0.19 \\
\hline A0A0V8TAG7 & GH74 xyloglucanase & 0.13 & 0.10 \\
\hline A0A0V8S7T2 & GH10 $\beta$-xylanase & 0.12 & 0.18 \\
\hline A0A0V8S3C7 & GH10 $\beta$-xylanase & 0.10 & 0.26 \\
\hline A0A0V8TBY6 & GH51 $\alpha$-L-arabinofuranosidase & 0.09 & 0.10 \\
\hline A0A0V8S1S2 & GH51 $\alpha$-L-arabinofuranosidase & 0.08 & 0.07 \\
\hline A0A0V8SI61 & GH3 $\beta$-glucosidase & 0.09 & 0.08 \\
\hline A0A0V8T8K6 & GH3 $\beta$-glucosidase & 0.06 & 0.04 \\
\hline A0A0V8TBD5 & AA10 LPMO & 0.05 & 0.14 \\
\hline \multirow[t]{2}{*}{ A0A0V8TBM3 } & GH43-CBM13 $\beta$-xylosidase & 0.05 & 0.06 \\
\hline & & C. fimi (PWP)1 & C. fimi (PWP)2 \\
\hline F4H4N7 & GH10-CBM $2 \beta$-xylanase & 14.50 & 15.89 \\
\hline P14090 & GH9 endoglucanase & 2.46 & 3.96 \\
\hline F4H710 & GH1 1 endo- $1,4-\beta$-xylanase & 1.12 & 1.67 \\
\hline F4H454 & GH10-CBM2 $\beta$-xylanase & 0.74 & 1.07 \\
\hline F4GZV4 & GH10-CBM13 $\beta$-xylanase & 0.49 & 0.25 \\
\hline P50899 & GH48-CBM2 exo-glucanase & 0.31 & 0.36 \\
\hline F4H413 & GH6 endoglucanase & 0.27 & 0.16 \\
\hline $\mathrm{F} 4 \mathrm{H} 2 \mathrm{~N} 5$ & GH13 $\alpha$-1,6-glucosidase & 0.26 & 0.30 \\
\hline F4H3U7 & GH9 endoglucanase & 0.25 & ND \\
\hline F4H0M7 & GH26-CBM23 endo-1,4- $\beta$-mannosidase & 0.19 & 0.17 \\
\hline F4GZL0 & GH5-CBM2 endoglucanase & 0.09 & 0.13 \\
\hline F4GZY2 & GH6-CBM2 endoglucacanase & 0.12 & 0.07 \\
\hline F4GY46 & GH10 $\beta$-xylanase & 0.12 & 0.11 \\
\hline F4GY55 & GH3-CBM1 $1 \beta$-glucosidase & 0.07 & 0.07 \\
\hline P50401 & GH6-CBM2 exoglucanase & 0.07 & 0.05 \\
\hline F4H4T8 & GH3 $\beta$-glucosidase & 0.03 & 0.02 \\
\hline F4GZV3 & GH62-CBM13 $\alpha$-L-arabinofuranosidase & 0.03 & 0.02 \\
\hline
\end{tabular}


Table 2 (continued)

\begin{tabular}{llll}
\hline Accession UNIPROT & CAZY domains and protein probable function description & emPAI\% \\
\hline F4H0T4 & GH3 $\beta$-glucosidase & 0.01 & 0.02 \\
F4H120 & GH3 $\beta$-glucosidase & 0.03 & ND \\
F4H5F6 & GH81-CBM16 endo-1,3(4)- $\beta$-glucanase & 0.02 & ND \\
F4H166 & GH51 $\alpha$-L-arabinofuranosidase & 0.01 & 0.01 \\
F4GZJ9 & GH74-CBM2 xyloglucanase & 0.01 & 0.01 \\
F4H7D2 & GH36 $\alpha$-galactosidase & 0.01 & 0.01 \\
F4H174 & GH64-CBM13 endo-1,3- $\beta$-D-glucosidase & ND & 0.01 \\
F4H7E7 & GH31 $\alpha$-glucosidase & 0.01 & 0.01 \\
F4H0J4 & GH51 $\alpha$-L-arabinofuranosidase & 0.01 & ND \\
\hline
\end{tabular}

$N D$ not detected

obtained in LEE $(10 \times)$, additional activities relevant to hemicelluloses deconstruction, such as $\alpha$-L-arabinofuranosidases and $\beta$-xylosidases were similar in both fractions (Table 3 ).

\section{Enzymatic hydrolysis of EBS by Cellulomonas sp. B6 enzymatic extracts}

Enzymatic hydrolysis of EBS using the xylanolytic extracts of Cellulomonas sp. B6 grown on WB was performed to test their hydrolytic efficiency and applicability in lignocellulosic bioprocesses. For this purpose, LEE alone or in combination with IE were used. As no concentration was required in the case of the intracellular extract, the fresh fraction of IE (before lyophilisation) was used, which had shown the same enzymatic activity as LIE. The different enzyme mixtures tested in enzymatic hydrolysis of EBS contained LEE and IE fractions with the following xylanase activity: $30 \mathrm{U} / \mathrm{mL}$ of LEE, $15 \mathrm{U} /$

Table 3 Activities of the lyophilised extracellular and intracellular enzyme fractions of Cellulomonas sp. B6 grown on WB. LEE $(10 \times)$ : 10 times concentrated extracellular enzyme obtained from lyophilised sample

\begin{tabular}{lll}
\hline Activity $(\mathrm{U} / \mathrm{mL})$ & & \\
\hline & LEE $(10 \times)$ & LIE \\
\hline Xylanase & $32(5.1)$ & $1.9(0.8)$ \\
CMCase & $3.6(0.5)$ & $0.5(0.2)$ \\
$\alpha$-arabinofuranosidase & $1(0.3)$ & $1.1(0.3)$ \\
$\beta$-xylosidase & $0.4(0.1)$ & $0.5(0.0)$ \\
$\beta$-glucosidase & $<0.1$ & $<0.1$ \\
Cellobiohydrolase & 0.1 & $<0.1$ \\
\hline
\end{tabular}

LIE lyophilised intracellular enzyme, CMCase carboxymethyl cellulase, $W B$ wheat bran. Average values and standard deviations (in parentheses) were calculated from biological triplicates
$\mathrm{mL}$ of LEE, 7.5 U/mL of LEE, $15 \mathrm{U} / \mathrm{mL}$ of LEE with $1.5 \mathrm{U} /$ $\mathrm{mL}$ of IE, $7.5 \mathrm{U} / \mathrm{mL}$ of LEE with $0.75 \mathrm{U} / \mathrm{mL}$ of IE, and $3 \mathrm{U} /$ $\mathrm{mL}$ of LEE with $0.3 \mathrm{U} / \mathrm{mL}$ of IE. Control experiments without the addition of enzyme extracts were also performed.

In all tested conditions, a xylose concentration higher than $2.5 \mathrm{~g} / \mathrm{L}$ was released from EBS (Fig. 4). Supplementation of the LEE fraction with IE fraction increased the amount of xylose released from biomass from 3.3 to $5.8 \mathrm{~g} / \mathrm{L}$, when 15 $\mathrm{U}_{\text {xylanase }} / \mathrm{mL}$ of LEE supplemented with $1.5 \mathrm{U}_{\text {xylanase }} / \mathrm{mL}$ of IE

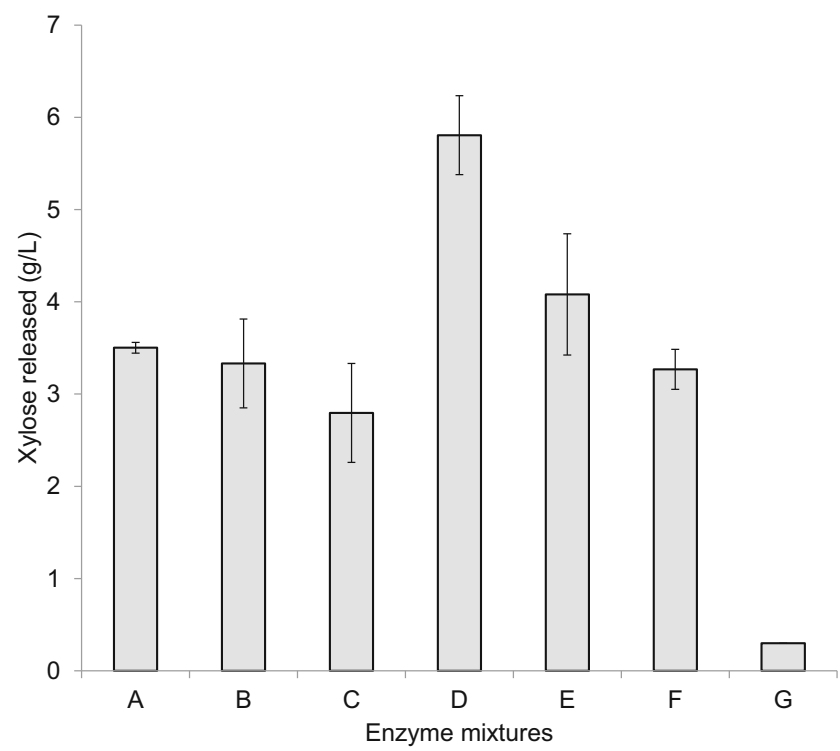

Fig. 4 Released xylose during hydrolysis of extruded barley straw (EBS) by using different mixtures of extracellular (LEE) and intracellular (IE) fractions of Cellulomonas sp. B6 grown on wheat bran (WB). The enzyme mixtures were the following: $30 \mathrm{U}_{\text {xylanase }} / \mathrm{mL}$ of LEE (A), 15 $\mathrm{U}_{\text {xylanase }} / \mathrm{mL}$ of LEE (B), $7.5 \mathrm{U}_{\text {xylanase }} / \mathrm{mL}$ of LEE (C), $15 \mathrm{U}_{\text {xylanase }} / \mathrm{mL}$ of LEE + 1.5 $\mathrm{U}_{\text {xylanase }} / \mathrm{mL}$ of IE (D), $7.5 \mathrm{U}_{\text {xylanase }} / \mathrm{mL}$ of LEE + 0.75 $\mathrm{U}_{\text {xylanase }} / \mathrm{mL}$ of IE $(\mathbf{E})$, and $3 \mathrm{U}_{\text {xylanase }} / \mathrm{mL}$ of LEE $+0.3 \mathrm{U} / \mathrm{mL}$ xylanase of IE (F). G: Substrate control without enzymes. Xylose concentration was determined by enzymatic colorimetric assay from D-xylose Kit (Megazyme) 
(Fig. 4B, D) and from 2.8 to $4.1 \mathrm{~g} / \mathrm{L}$ when $7.5 \mathrm{U}_{\text {xylanase }} / \mathrm{mL}$ of LEE was supplemented with $0.75 \mathrm{U}_{\text {xylanase }} / \mathrm{mL}$ of IE (Fig. 4C, E), probably due to additional activities, involved in hemicellulose degradation, present in the IE. This result was further confirmed by performing thin layer chromatography (TLC) analyses of the hydrolysates of EBS, observing an increase in the conversion of oligosaccharides to xylose in enzyme mixtures containing IE. A significant amount of short chain soluble oligosaccharides were also produced (Supplementary Fig. S1). Hence, supplementing the extracellular enzymatic extracts (LEE) with the intracellular (IE) fraction significantly enhanced the liberation of xylose from EBS.

\section{Discussion}

In the current work, we studied the feasibility of using different carbon sources - purified polysaccharides and cheap agroindustrial residues - as selective inducers of (hemi)cellulolytic activity in C. fimi B-402 and Cellulomonas sp. B6, already known as lignocellulose-active bacteria. Altogether, both strains showed greater xylanolytic than cellulolytic activity. While Cellulomonas sp. B6 showed higher activity on lignocellulosic complex biomass, cellulose-rich (chemically notmodified) substrates (SF and PWP) were better inducers for the extracellular production of xylanases by $C$. fimi. In addition, although the growth on complex biomass has served as a successful strategy to enhance xylanolytic activity in several microorganisms (Saratale et al. 2010; Takenaka et al. 2019), it has also been proven that cellulosic substrates can induce the production of xylanases in C. fimi (Wakarchuk et al. 2016). The use of residues and by-products as substrates for microbial growth has the advantage of being an inexpensive strategy for inducing the production of enzymes (Lopes et al. 2018). Interestingly, we found that low-value substrates of wheat bran (WB) and pre-treated waste paper (PWP) were the best inducers of xylanase activity in Cellulomonas sp. B6 and C. fimi, respectively. Proteomic analysis revealed that all the extracellular xylanases (GH10, GH11) and cellulose active enzymes (GH6, GH9, GH48) encoded in Cellulomonas sp. B6 genome were secreted by growth on WB. These findings, along with previously reported assay, confirm that complex substrates, such as WB, are highly suitable for the production of CAZYmes, especially those active on hemicellulose, by Cellulomonas sp. B6 (Piccinni et al. 2019). Eleven enzymes belonging to families GH6, GH48, GH9, GH10 and GH11, commonly associated with endo-xylanase and endoglucanase activity, were also secreted by $C$. fimi growing on PWP. By contrast, other substrates like CMC, WB or xylan have been reported to induce the secretion of only some of these enzymes in the model strain C. fimi ATCC 484 (Wakarchuk et al. 2016; Spertino et al. 2018). Moreover, as described by Wakarchuk et al. (2016) the genome of C. fimi ATCC 484 encodes 5 GH10 and 1 GH11 predicted xylanases. In the current study, PWP induced the secretion of 4 GH10 and 1 GH11, which is the maximum amount of secreted xylanases reported for $C$. fimi to date.

All of the above-mentioned carbohydrate-active enzymes have a broad range of industrial applications. Therefore, their production, catalytic efficiency and activity-preservation are essential factors from a biotechnological perspective. Benchscale bioreactors have resulted to be useful tools for the identification and validation of key parameters involved in the scaling-up of bioprocesses (Marques et al. 2010). In the current study, the xylanase activity of both strains growing in a stirred tank bioreactor employing their preferred substrates was comparable with the one obtained in shake flask cultures. Conversely, some researchers have reported a significant yield loss by transferring the enzyme fermentation to bench-scale bioreactor (Kumar et al. 2009; Garai and Kumar 2013). Oxygen limitation, reduced availability of insoluble substrate, shear induced by agitation, dilution, substrate and product concentration are amongst the main listed drawbacks (Yegin et al. 2017). Remarkably, Cellulomonas sp. B6 and C. fimi showed a good performance in bench-scale bioreactors, foreseeing a great chance of efficient enzyme production on an industrial scale. It is important to note that $1 \% \mathrm{w} / \mathrm{w}$ PWP resulted in a dense and slimy suspension, which was a difficult medium to work with, especially because it can easily cause inhomogeneity in the bioreactor. The xylanase activity in the culture broth of $C$. fimi continuously increased during the fermentation. Thus, longer fermentation times should be examined to determine the maximum xylanase activity that may be achieved by $C$. fimi grown on PWP in a bioreactor. However, increasing fermentation time also increases the production costs. Process optimisation, including different agitation rates, addition of antifoam or modifications in substrate concentration, could be accompanied by improved performance and reduced operating times. The profiles of $\mathrm{CO}_{2}$ level in exhaust gas, DO concentration and xylanase activity in the culture medium suggest that the xylanase production by Cellulomonas sp. B6 on WB might have a growth-associated characteristic. A similar trend was observed by $\mathrm{Xu}$ et al. (2005) when the production of xylanase extract by Pseudomonas sp. WLUN024 was studied.

Concentration of enzymes is an important step in their production, especially if it helps to overcome the need for preservation and transportation at low temperatures. Many commercial enzyme preparations consist of concentrated culture broth with additives that stabilise enzymatic activity (Poletto et al. 2015). In the current work, the extracellular extracts from Cellulomonas sp. B6 retained $80 \%$ of xylanase activity after lyophilisation and further re-suspension, without the need of stabilising additives. This is a promising result since freezedrying is a simple method for enzyme preservation but is usually associated with protein denaturation (Berghout et al. 
2015). Analysis of different glycoside hydrolase activities in the lyophilised samples showed that the extracellular enzyme fraction contained activities for polymeric hydrolysis in much higher quantities than activities for side-chain sugar hydrolysis. However, side activities were abundant in the intracellular enzyme fraction. Similarly, Rajoka (2005) reported that the cell-free supernatants of Cellulomonas flavigena NIAB 441 culture exhibited greater endo-xylanase activity than cell-associated $\beta$-xylosidase activity.

Lyophilisation allowed us to concentrate the xylanase activity up to 10-fold and to use the extracts for hydrolysis of extruded barley straw (EBS). In order to improve the process, we supplemented the extracellular extract with the intracellular enzymes released by sonication. Using the enzyme cocktails containing different amount of LEE and IE fractions of Cellulomonas sp. B6 for enzymatic hydrolysis experiments of EBS resulted in the release of xylose and xylooligosaccharides as the main soluble products. Supplementing LEE samples with appropriate amounts of IE fraction significantly enhanced xylose release from EBS. Addition of appropriate xylanases during the enzymatic deconstruction of pre-treated barley straw is of great importance, since xylanase supplementation can significantly improve the efficiency of cellulose-hydrolysis (García-Aparicio et al. 2007). Moreover, hydrolysis by xylanases alone can result in promising bio-products like prebiotic xylo-oligomers or monomer xylose which may be then converted into high-value products (e.g. xylitol). Hence, LEE and IE from Cellulomonas sp. B6 may be interesting biotechnological candidates for biomass hydrolysis to produce xylo-oligomers, xylose or enhance enzymatic cellulose deconstruction.

We have concluded that the xylanolytic activity of Cellulomonas sp. B6 and C. fimi was differentially induced by varying the substrates utilised for its growth. Low-cost lignocellulosic residues were the most suitable inducers of secreted hemicellulases, which were then efficient for biomass decomposition into xylose and xylooligosaccharides. Fermentation in a bench-scale bioreactor followed by supernatant lyophilisation was a successful tool to increase enzyme production and concentrate enzymatic activity. The larger scale-up parameterisation and the design of xylanolytic cocktails are some of the further objectives that emerge from this research. Thorough study of the molecular mechanisms involved in the activity could also be useful strategy to understand and improve the (hemi)cellulolytic capacity of the strains.

Supplementary Information The online version contains supplementary material available at https://doi.org/10.1007/s00253-021-11305-y.

Acknowledgments J Fermi Biotechnology Ltd. is acknowledged for the assistant in fermentation experiments.
EC and OO are Research Career members from CONICET, JT and MG hold Doctoral fellowships from CONICET and are PhD students from the FBMC and QB Departments of FCEN, University of Buenos Aires (UBA).

Availability of data and materials The mass spectrometry proteomics data have been deposited to the ProteomeXchange Consortium via the PRIDE [1] partner repository with the dataset identifier PXD022718 (available upon publication). Strain Cellulomonas sp. B6 has been deposited in public collections DSMZ and NCIMB, as DSM 107934 and NCIMB 15124, respectively.

Code availability Not applicable

Authors' contributions $\mathrm{OMO}$ and $\mathrm{SB}$ conducted experiments, analysed the data and wrote the manuscript. SG, MMG, JT, DJ and AF conducted experiments. PV was responsible for proteomic analysis. EC and CF conceived and designed the research, were responsible for funding acquisition and corrected the manuscript. All authors read, corrected and approved the manuscript.

Funding Open access funding provided by Budapest University of Technology and Economics. This work was supported by project grants ANCYP PICT2016-4695 (ARG); binational cooperation project MINCYT HU/17/04 (ARG) and NRDIO TÉT 15 AR (HUN) and project TNN_16-123305 of the National Research, Development and Innovation Fund of Hungary. The research reported in this paper and carried out at BME has been supported by the NRDI Fund (TKP2020 IES, Grant No. BME-IE-BIO) based on the charter of bolster issued by the NRDI Office under the auspices of the Ministry for Innovation and Technology.

\section{Declarations}

Ethics approval This article does not contain any studies with human participants or animals performed by any of the authors.

Consent to participate Not applicable

Consent for publication Not applicable

Conflict of interest The authors declare they have no conflict of interest.

Open Access This article is licensed under a Creative Commons Attribution 4.0 International License, which permits use, sharing, adaptation, distribution and reproduction in any medium or format, as long as you give appropriate credit to the original author(s) and the source, provide a link to the Creative Commons licence, and indicate if changes were made. The images or other third party material in this article are included in the article's Creative Commons licence, unless indicated otherwise in a credit line to the material. If material is not included in the article's Creative Commons licence and your intended use is not permitted by statutory regulation or exceeds the permitted use, you will need to obtain permission directly from the copyright holder. To view a copy of this licence, visit http://creativecommons.org/licenses/by/4.0/.

\section{References}

Akhtar N, Goyal D, Aanchal GA (2016) Biodiversity of cellulase producing bacteria and their applications. Cellul Chem Technol 50: 983-995 
Apprich S, Tirpanalan Ö, Hell J, Reisinger M, Böhmdorfer S, Siebenhandl-Ehn S, Novalin S, Kneifel W (2014) Wheat bran-based biorefinery 2: Valorization of products. LWT Food Sci Technol 56: 222-231. https://doi.org/10.1016/j.lwt.2013.12.003

Arumugam N, Anandakumar S (2016) Mini review on corncob biomass: a potential resource for value-added metabolites. Eur J Exp Biol 6: $9-13$

Astolfi V, Astolfi AL, Mazutti MA, Rigo E, Di Luccio M, Camargo AF, Dalastra C, Kubeneck S, Fongaro G, Treichel H (2019) Cellulolytic enzyme production from agricultural residues for biofuel purpose on circular economy approach. Bioprocess Biosyst Eng 42:677-685. https://doi.org/10.1007/s00449-019-02072-2

Ballesteros M (2010) Enzymatic hydrolysis of lignocellulosic biomass. Bioalcohol Prod Biochem Convers Lignocellul Biomass:159-177. https://doi.org/10.1533/9781845699611.2.159

Bedő S, Antal B, Rozbach M, Fehér A, Fehér C (2019) Optimised fractionation of wheat bran for arabinose biopurification and xylitol fermentation by Ogataea zsoltii within a biorefinery process. Ind Crop Prod 139:111504. https://doi.org/10.1016/j.indcrop.2019. 111504

Berghout JAM, Venema P, Boom RM, Van der Goot AJ (2015) Comparing functional properties of concentrated protein isolates with freeze-dried protein isolates from lupin seeds. Food Hydrocoll 51:346-354. https://doi.org/10.1016/j.foodhyd.2015.05. 017

Bertani G (1951) Studies on lysogenesis. I The mode of phage liberation by lysogenic Escherichia coli J Bacteriol 62:293-300. https://doi. org/10.1128/JB.62.3.293-300.1951

Bhardwaj N, Kumar B, Verma P (2019) A detailed overview of xylanases: an emerging biomolecule for current and future prospective. Bioresour Bioprocess 6:40. https://doi.org/10.1186/s40643019-0276-2

Das A, Paul T, Jana A, Halder SK, Ghosh K, Maity C, Mohapatra PKD, Pati BR, Mondal KC (2013) Bioconversion of rice straw to sugar using multizyme complex of fungal origin and subsequent production of bioethanol by mixed fermentation of Saccharomyces cerevisiae MTCC 173 and Zymomonas mobilis MTCC 2428. Ind Crop Prod 46:217-225. https://doi.org/10.1016/j.indcrop.2013.02. 003

De Bhowmick G, Sarmah AK, Sen R (2018) Lignocellulosic biorefinery as a model for sustainable development of biofuels and value added products. Bioresour Technol 247:1144-1154. https://doi.org/10. 1016/j.biortech.2017.09.163

Duque A, Manzanares P, Ballesteros M (2017) Extrusion as a pretreatment for lignocellulosic biomass: Fundamentals and applications. Renew Energy 114:1427-1441. https://doi.org/10.1016/j.renene. 2017.06.050

Fehér C (2018) Novel approaches for biotechnological production and application of L-arabinose. J Carbohydr Chem 37:251-284. https:// doi.org/10.1080/07328303.2018.1491049

Garai D, Kumar V (2013) Response surface optimization for xylanase with high volumetric productivity by indigenous alkali tolerant Aspergillus candidus under submerged cultivation. 3 Biotech 3: 127-136. https://doi.org/10.1007/s13205-012-0077-1

García-Aparicio MP, Ballesteros M, Manzanares P, Ballesteros I, González A, José Negro M (2007) Xylanase contribution to the efficiency of cellulose enzymatic hydrolysis of barley straw. Appl Biochem Biotechnol 137-140:353-365. https://doi.org/10.1007/ s12010-007-9064-0

Ghio S, Di Lorenzo GS, Lia V, Talia P, Cataldi A, Grasso D, Campos E (2012) Isolation of Paenibacillus sp. and Variovorax sp. strains from decaying woods and characterization of their potential for cellulose deconstruction. Int J Biochem Mol Biol 3:352-364

Ishihama Y, Oda Y, Tabata T, Sato T, Nagasu T, Rappsilber J, Mann M (2005) Exponentially modified protein abundance index (emPAI) for estimation of absolute protein amount in proteomics by the number of sequenced peptides per protein. Mol Cell Proteomics 4: 1265-1272. https://doi.org/10.1074/mcp.M500061-MCP200

Islam F (2019) Isolation and characterization of cellulase-producing bacteria from sugar industry waste. Am J Biosci 7:16. https://doi.org/10. 11648/j.ajbio.20190701.13

Juturu V, Wu JC (2014) Microbial cellulases: Engineering, production and applications. Renew Sust Energ Rev 33:188-203. https://doi. org/10.1016/j.rser.2014.01.077

Kane SD, French CE (2018) Characterisation of novel biomass degradation enzymes from the genome of Cellulomonas fimi. Enzym Microb Technol 113:9-17. https://doi.org/10.1016/j.enzmictec. 2018.02.004

Kumar KS, Manimaran A, Permaul K, Singh S (2009) Production of $\beta$ xylanase by a Thermomyces lanuginosus MC 134 mutant on corn cobs and its application in biobleaching of bagasse pulp. J Biosci Bioeng 107:494-498. https://doi.org/10.1016/j.jbiosc.2008.12.020

Lopes AM, Ferreira Filho EX, Moreira LRS (2018) An update on enzymatic cocktails for lignocellulose breakdown. J Appl Microbiol 125: 632-645. https://doi.org/10.1111/jam.13923

Maitan-Alfenas GP, Visser EM, Guimarães V r M (2015) Enzymatic hydrolysis of lignocellulosic biomass: Converting food waste in valuable products. Curr Opin Food Sci 1:44-49. https://doi.org/10. 1016/j.cofs.2014.10.001

Maki M, Leung KT, Qin W (2009) The prospects of cellulase-producing bacteria for the bioconversion of lignocellulosic biomass. Int J Biol Sci 5:500-516. https://doi.org/10.7150/ijbs.5.500

Marques MPC, Cabral JMS, Fernandes P (2010) Bioprocess scale-up: Quest for the parameters to be used as criterion to move from microreactors to lab-scale. J Chem Technol Biotechnol 85:11841198. https://doi.org/10.1002/jctb.2387

Miller GL (1959) Use of dinitrosalicylic acid reagent for determination of reducing sugar. Anal Chem 31:426-428. https://doi.org/10.1021/ ac60147a030

Ontañon OM, Ghio S, de Villegas RMD, Piccinni FE, Talia PM, Cerutti ML, Campos E (2018) EcXyl43 $\beta$-xylosidase: Molecular modeling, activity on natural and artificial substrates, and synergism with endoxylanases for lignocellulose deconstruction. Appl Microbiol Biotechnol 102:6959-6971. https://doi.org/10.1007/s00253-0189138-7

Piccinni F, Murua Y, Ghio S, Talia P, Rivarola M, Campos E (2016) Draft genome sequence of cellulolytic and xylanolytic Cellulomonas sp. strain B6 isolated from subtropical forest soil. Genome Announc 4:5-10. https://doi.org/10.1128/genomeA. 00891-16

Piccinni FE, Ontañon OM, Ghio S, Sauka DH, Talia PM, Rivarola ML, Valacco MP, Campos E (2019) Secretome profile of Cellulomonas sp. B6 growing on lignocellulosic substrates. J Appl Microbiol 126: 811-825. https://doi.org/10.1111/jam.14176

Poletto P, Borsói C, Zeni M, da Silveira MM (2015) Downstream processing of pectinase produced by Aspergillus niger in solid state cultivation and its application to fruit juices clarification. Food Sci Technol 35:391-397. https://doi.org/10.1590/1678-457X.6659

Rajoka MI (2005) Regulation of synthesis of endo-xylanase and $\beta$ xylosidase in Cellulomonas flavigena: A kinetic study. World J Microbiol Biotechnol 21:463-469. https://doi.org/10.1007/s11274004-2396-9

Saratale GD, Saratale RG, Lo YC, Chang JS (2010) Multicomponent cellulase production by Cellulomonas biazotea NCIM-2550 and its applications for cellulosic biohydrogen production. Biotechnol Prog 26:406-416. https://doi.org/10.1002/btpr.342

Shinoda K, Tomita M, Ishihama Y (2009) emPAI Calc-for the estimation of protein abundance from large-scale identification data by liquid chromatography-tandem mass spectrometry. Bioinformatics 26: 576-577. https://doi.org/10.1093/bioinformatics/btp700

Sipos B, Benkő Z, Dienes D, Réczey K, Viikari L, Siika-Aho M (2010) Characterisation of specific activities and hydrolytic properties of 
cell-wall-degrading enzymes produced by Trichoderma reesei rut C30 on different carbon sources. Appl Biochem Biotechnol 161: 347-364. https://doi.org/10.1007/s12010-009-8824-4

Siqueira JGW, Rodrigues C, de Souza Vandenberghe LP, Woiciechowski AL, Soccol CR (2020) Current advances in on-site cellulase production and application on lignocellulosic biomass conversion to biofuels: A review. Biomass Bioenergy 132:105419. https://doi.org/10.1016/j.biombioe.2019.105419

Sluiter A, Hames B, Ruiz R, Scarlata C, Sluiter J, Templeton D, Crocker D (2012) Determination of structural carbohydrates and lignin in biomass. Technical Report NREL/TP-510-42618. National Renewable Energy Laboratory, Golden, CO

Spertino S, Boatti L, Icardi S, Manfredi M, Cattaneo C, Marengo E, Cavaletto M (2018) Cellulomonas fimi secretomes: In vivo and in silico approaches for the lignocellulose bioconversion. J Biotechnol 270:21-29. https://doi.org/10.1016/j.jbiotec.2018.01.018

Takenaka M, Lee JM, Kahar P, Ogino C, Kondo A (2019) Efficient and supplementary enzyme cocktail from Actinobacteria and plant biomass induction. Biotechnol J 14:1-8. https://doi.org/10.1002/biot. 201700744

Wakarchuk WW, Brochu D, Foote S, Robotham A, Saxena H, Erak T, Kelly J (2016) Proteomic analysis of the secretome of Cellulomonas fimi ATCC 484 and Cellulomonas flavigena ATCC 482. PLoS One 11:1-13. https://doi.org/10.1371/journal.pone.0151186

Wang L, Sharifzadeh M, Templer R, Murphy RJ (2012) Technology performance and economic feasibility of bioethanol production from various waste papers. Energy Environ Sci 5:5717-5730. https://doi. org/10.1039/c2ee02935a

Xu ZH, Bai YL, Xu X, Shi JS, Tao WY (2005) Production of alkali-tolerant cellulase-free xylanase by Pseudomonas sp. WLUN024 with wheat bran as the main substrate. World J Microbiol Biotechnol 21:575-581. https://doi.org/10.1007/ s11274-004-3491-7

Yegin S, Buyukkileci AO, Sargin S, Goksungur Y (2017) Exploitation of agricultural wastes and by-products for production of Aureobasidium pullulans Y-2311-1 xylanase: Screening, bioprocess optimization and scale up. Waste Biomass Valorization 8:9991010. https://doi.org/10.1007/s12649-016-9646-6

Publisher's note Springer Nature remains neutral with regard to jurisdictional claims in published maps and institutional affiliations. 